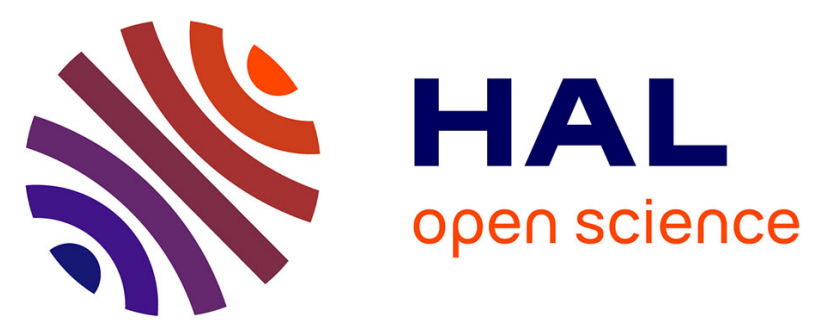

\title{
Anomalously deep mantle transition zone below Central Europe: Evidence of lithospheric instability
}

György Hetényi, Graham W Stuart, Gregory A Houseman, Frank Horváth, Endre Hegedűs, Ewald Brückl

\section{- To cite this version:}

György Hetényi, Graham W Stuart, Gregory A Houseman, Frank Horváth, Endre Hegedűs, et al.. Anomalously deep mantle transition zone below Central Europe: Evidence of lithospheric instability. Geophysical Research Letters, 2009, 36 (21), pp.L21307. 10.1029/2009GL040171 . insu-03524032

\section{HAL Id: insu-03524032 \\ https://hal-insu.archives-ouvertes.fr/insu-03524032}

Submitted on 13 Jan 2022

HAL is a multi-disciplinary open access archive for the deposit and dissemination of scientific research documents, whether they are published or not. The documents may come from teaching and research institutions in France or abroad, or from public or private research centers.
L'archive ouverte pluridisciplinaire HAL, est destinée au dépôt et à la diffusion de documents scientifiques de niveau recherche, publiés ou non, émanant des établissements d'enseignement et de recherche français ou étrangers, des laboratoires publics ou privés.

$$
\text { Copyright }
$$




\title{
Anomalously deep mantle transition zone below Central Europe: Evidence of lithospheric instability
}

\author{
György Hetényi, ${ }^{1,2,3,4}$ Graham W. Stuart, ${ }^{1}$ Gregory A. Houseman, ${ }^{1}$ Frank Horváth, ${ }^{3}$ \\ Endre Hegedüs, ${ }^{5}$ and Ewald Brückl ${ }^{6}$ \\ Received 23 July 2009; revised 10 September 2009; accepted 13 October 2009; published 11 November 2009.
}

[1] The depths of the 410 and $660 \mathrm{~km}$ phase transitions provide critical information on the thermal state of the mantle transition zone (MTZ) and, by implication, on the circulation of the upper mantle. We analyze converted seismic waves to produce a high resolution image of these discontinuities beneath the Pannonian Basin of Central Europe. Models to explain the extension of the basin in the Middle Miocene involve subduction roll-back and gravitational instability of an over-thickened lithosphere. We find that cold dense material appears to have accumulated in the MTZ, consistent with the idea of supply from several subduction episodes, or upper mantle overturn. Variation in depth of the $660 \mathrm{~km}$ discontinuity by as much as $40 \mathrm{~km}$ suggests that cold lithospheric mantle is ponding on top of this phase transition. Where the phase transition is deepest, eventual transfer of this material into the lower mantle may be expected to develop. Citation: Hetényi, G., G. W. Stuart, G. A. Houseman, F. Horváth, E. Hegedüs, and E. Brückl (2009), Anomalously deep mantle transition zone below Central Europe: Evidence of lithospheric instability, Geophys. Res. Lett., 36, L21307, doi:10.1029/2009GL040171.

\section{Introduction}

[2] Formation of the Pannonian Basin in the Middle Miocene occurred essentially by rapid extension of orogenic terranes during their escape from the Alpine collision zone towards the east [Horváth, 1993]. These processes are inferred to have been driven by a subduction system operating on the Eastern Carpathians [e.g., Horváth and Royden, 1981]. The relatively large ratio of mantle thinning factor to crustal thinning factor, as determined by subsidence histories in the basin, implies that gravitational instability of the lithospheric mantle [Houseman and Gemmer, 2007] was also a significant driving force. Detachment of the Pannonian lower lithosphere could have occurred either in the Alpine collision zone before escape [Horváth et al., 2005a] or during and after extension [Houseman and Gemmer, 2007]. These mechanisms require that subducted or delaminated lithosphere has descended into the upper mantle and has dis-

\footnotetext{
${ }^{1}$ School of Earth and Environment, University of Leeds, Leeds, UK.

${ }^{2}$ Laboratoire de Géologie, UMR8538, Ecole Normale Supérieure, CNRS, Paris, France.

${ }^{3}$ Department of Geophysics, Eötvös University, Budapest, Hungary.

${ }^{4}$ Department of Earth Sciences, ETH Zurich, Zurich, Switzerland.

${ }^{5}$ Eötvös Loránd Geophysical Institute, Budapest, Hungary.

${ }^{6}$ Institute of Geodesy and Geophysics, Technische Universität Wien, Vienna, Austria.
}

Copyright 2009 by the American Geophysical Union. 0094-8276/09/2009GL040171 placed hot material which has moved upwards beneath the extending basin. Models of mantle convection imply that the effects of such an overturn should extend throughout the upper mantle, but may have had minimal impact so far on the lower mantle because the time-scale for viscous deformation of the lower mantle is so much greater than that of the upper mantle, and the extension finished only $10 \mathrm{Myr}$ ago. To the first order, regional P-wave tomographic inversions beneath the Pannonian Basin [Wortel and Spakman, 2000; Piromallo and Morelli, 2003] support this model by showing that anomalously fast material occupies the mantle transition zone (MTZ), beneath anomalously slow upper mantle. The vertical extent of the fast anomaly is, however, not clear as tomographic techniques do not have sufficient resolution in depth.

[3] To quantify the extent and impact of the mantle dynamical processes described above, we examine the deflection of the major phase change interfaces bounding the MTZ by computing receiver functions (RF) from a highresolution broad-band seismic dataset combining a recent array deployment across the Pannonian Basin and permanent stations. These phase changes are olivine $\rightarrow$ wadsleyite at $\sim 410 \mathrm{~km}$, and ringwoodite $\rightarrow$ perovskite + magnesiowüstite at $\sim 660 \mathrm{~km}$ depth. The positive Clapeyron slope of the $410 \mathrm{~km}$ transition encourages vertical transport because the phase transition is elevated in cold downwelling regions, whereas the $660 \mathrm{~km}$ transition, with negative Clapeyron slope, is depressed in cold regions and thus resists exchange of material with the lower mantle. A thickened (thinned) mantle transition zone is usually interpreted in terms of a colder (warmer) thermal regime than the laterally averaged mantle temperatures [e.g., Lebedev et al., 2002]. In Central Europe, we discover that while the top of the MTZ is close to its expected depth $(410 \mathrm{~km})$, its bottom is clearly depressed below $660 \mathrm{~km}$ and shows significant undulations. We argue that these undulations arise from the uneven accumulation of cold material from successive episodes of subduction and/or gravitational instability of the lithospheric mantle. The depressed areas of the $660 \mathrm{~km}$ discontinuity beneath the Pannonian Basin indicate the places where local downwelling into the lower mantle may develop, if not already occurring.

\section{Geodynamic Setting and Scenario}

[4] Central Europe has been a tectonically active zone since the Cretaceous and throughout the Cenozoic. The region, lying in the eastern extension of the main collision zone between Africa and Europe, the Alps, has experienced a complex geodynamic history. At the end of the Cretaceous and during the Palaeogene, a mosaic of continental terranes 


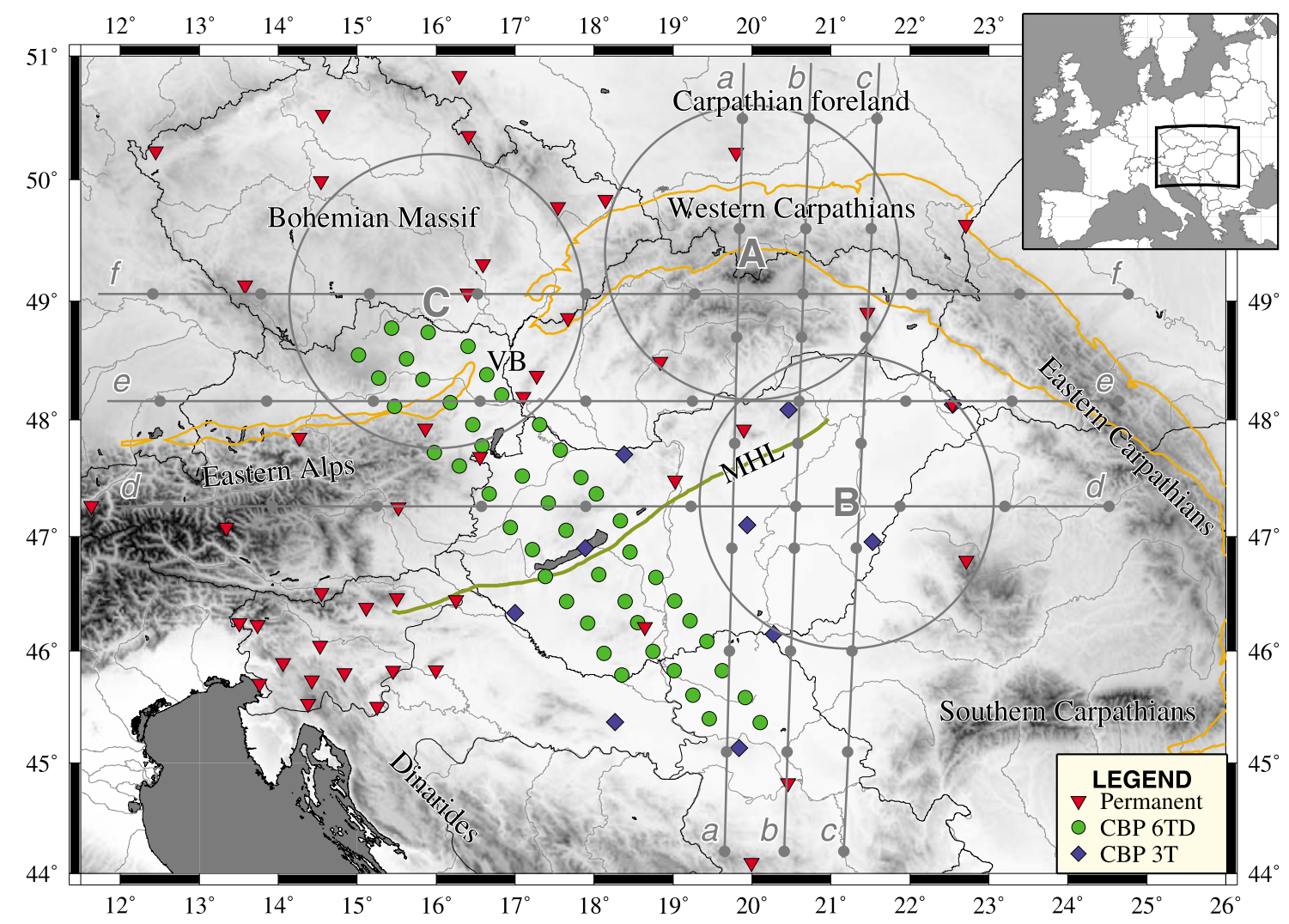

Figure 1. Study area and station location for the Carpathian Basins Project (2005-2007). The Pannonian Basin is surrounded by mountain ranges resulting from several episodes of collision and subduction between Africa and Europe. VB, Vienna pull-apart basin. MHL, Mid-Hungarian Line, dividing two micro-terranes (Alcapa to the North and Tisza to the South) in the Pannonian Basin. The orange line shows the extent of the flysch formation of the Outer Carpathians. Permanent broadband station data were accessed through GEOFON (http://geofon.gfz-potsdam.de/geofon/), ORFEUS (http://www.orfeus-eu.org/), and IRIS (http://www.iris.edu/hq/), as well as from the Geodetic and Geophysical Research Institute of the Hungarian Academy of Sciences. Temporary stations used Guralp 6TD and 3T instruments. Migrated profiles a-f are shown on Figure 2 with dots at $100 \mathrm{~km}$ intervals, circles $A-C$ are $140 \mathrm{~km}$ radii areas for waveform stacking (see Figure S3).

and Neo-Tethys-related oceanic lithosphere fragments governed the evolution of this area [Csontos and Vörös, 2004; Stampfli and Borel, 2004; Schmid et al., 2008]. The successive subduction and accretion of these micro-terranes set the scene for the formation of the extensional Pannonian Basin, with deep sedimentary basins, and the rise of the surrounding mountain ranges, the Carpathians and the Dinarides (Figure 1). The latest and currently most active part in this range is the Vrancea zone, where Eastern and Southern Carpathians meet [Bada et al., 1999; Lorinczi and Houseman, 2009].

[5] Geophysical measurements in the Pannonian Basin show that the crust and the lithosphere are thinned beneath the entire basin, and that the thermal regime is warmer than the global continental average [Horváth et al., 2005b; Środa et al., 2006; Brückl et al., 2007]. Beneath the lithosphere, the asthenosphere is thought to be hot, as indicated by magnetotelluric measurements [e.g., Ádám et al., 1989] and seismic tomography [Wortel and Spakman, 2000; Piromallo and Morelli, 2003]. These latter studies also show clear $(>1.5-2 \%)$ fast anomalies in the MTZ beneath all of the Pannonian Basin, which the authors interpret as remnants of recent subduction episodes. Concerning the Vrancea region, the same tomography results show a separate sub-vertical fast anomaly, extending down to $\sim 400 \mathrm{~km}$ depth.

\section{Data and Processing}

[6] Figure 1 shows the broad-band seismological stations providing data for our study: three profiles from the Carpathian Basins Project (CBP) operated for 16 months, and we obtained data from permanent stations over a 4-year period. We use the receiver function technique that captures P- to S-wave conversions at velocity discontinuities within the Earth [Langston, 1979]. Frequencies between 0.033 and $0.25 \mathrm{~Hz}$ were kept by filtering in order to detect conversions from the MTZ. The RF delay times were then converted to depth using the regional PM05 velocity-model [Piromallo and Morelli, 2003], and the conversion points (Figure S1 of the auxiliary material) migrated to their correct geometric positions $[\mathrm{Zhu}, 2000] .^{1}$ These converted signals were

\footnotetext{
${ }^{1}$ Auxiliary materials are available in the HTML. doi:10.1029 2009GL040171.
} 

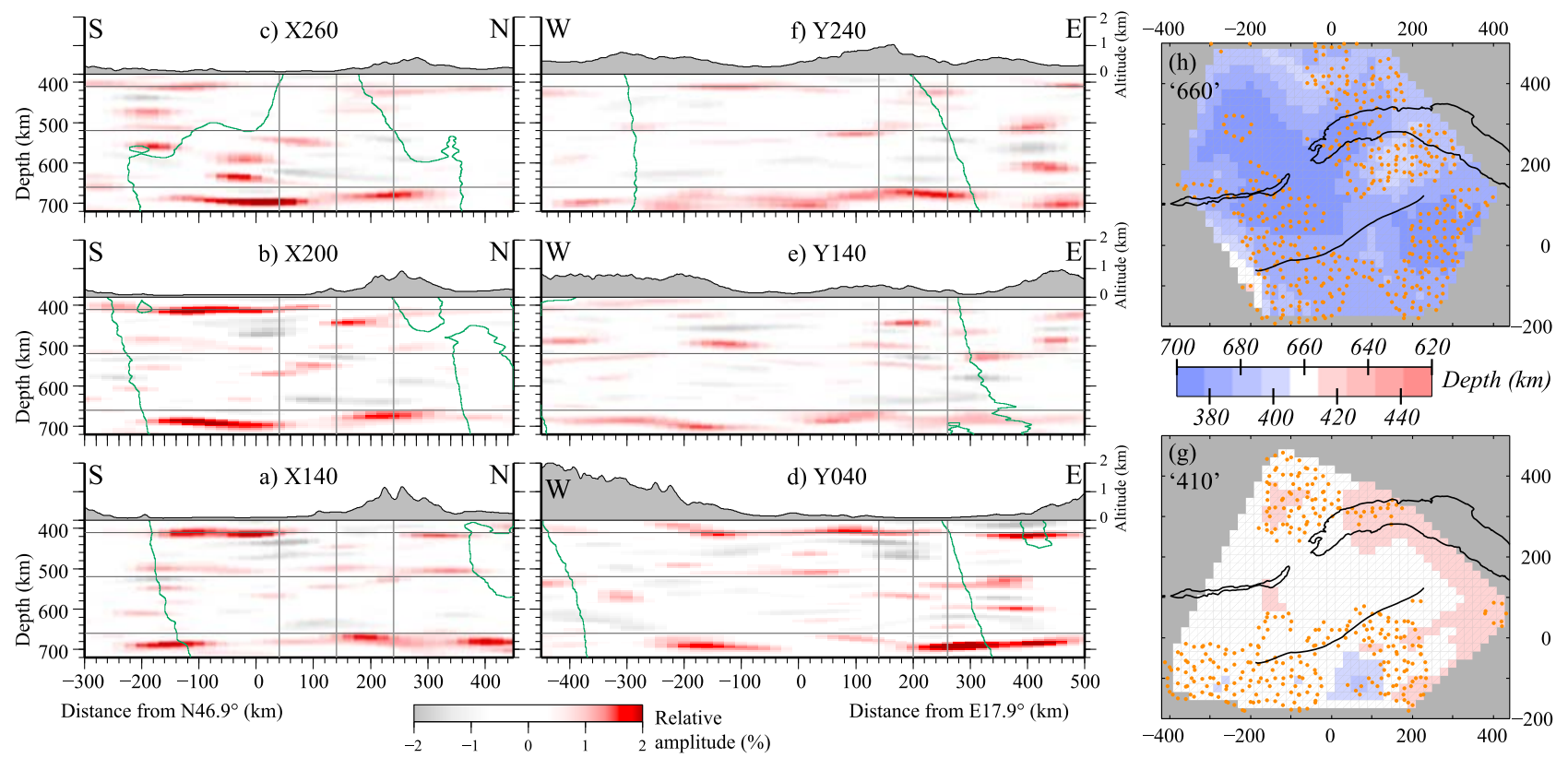

Figure 2. Mantle transition zone structure presented in profile as well as in map view. Migrated receiver function profiles of the mantle transition zone along $(\mathrm{a}-\mathrm{c}) \mathrm{S}-\mathrm{N}$ and $(\mathrm{d}-\mathrm{f}) \mathrm{W}-\mathrm{E}$ directions (see Figure 1 for locations, as well as the averaged topography above each profile for reference). Red colors indicate positive impedance contrast with depth. Thin horizontal lines are drawn at 410, 520 and $660 \mathrm{~km}$ depth. Thin vertical lines show location of intersections with perpendicular profiles. Thin green lines bound well-resolved areas of the image, i.e., with more than $20 \%$ of the maximum ray coverage $(\mathrm{g}-\mathrm{h})$. Map view of the mantle transition zone interface depth beneath the study area. First, the (g) 410 and (h) $660 \mathrm{~km}$ discontinuities were picked manually (orange dots) and interpolated to produce depth maps. Depths were picked only within the well resolved part of the image (i.e., more than $20 \%$ of the maximum ray coverage); the remaining part of the image is in grey. The significant thickening is caused by the deflection of the ' 660 ', the ' 410 ' being close to its expected depth. The Mid-Hungarian Line and the Carpathian flysch are drawn for reference.

binned into voxels and smoothed, accounting for the size of the Fresnel zone and the vertical resolution of the RF, to produce the final images of the MTZ discontinuity depths. Details of data and processing are given in the auxiliary material.

\section{Results}

[7] Six slices of our 3-D migrated image (see Figure 1 for locations), representative of the observed features are shown on Figures $2 \mathrm{a}-2 \mathrm{f}$. Relative to the typical depth of the 410 and $660 \mathrm{~km}$ discontinuities ('410' and '660' hereinafter), we can observe that:

[8] 1. The converted amplitudes associated with the ' 410 ', are sub-horizontal, and lie at their normal depth, with deviations rarely exceeding $10 \mathrm{~km}$.

[9] 2. On the other hand, the conversions from the ' 660 ' are imaged clearly deeper than the global average, with apparent depths ranging from $\sim 665 \mathrm{~km}$ to $\sim 700 \mathrm{~km}$.

[10] 3. Significantly weaker and localized conversion amplitudes are observed at or around the proposed discontinuity at $520 \mathrm{~km}$ depth (wadsleyite $\rightarrow$ ringwoodite phase change).

[11] These observations imply that the mantle transition zone below the Pannonian Basin is in general thicker than the global average $(250 \mathrm{~km}$ estimated by Chevrot et al. [1999]; $242 \pm 2 \mathrm{~km}$ by Lawrence and Shearer [2006]) by up to $40 \mathrm{~km}$. Lateral variations in thickness can be assessed on the RF waveforms (see auxiliary material) as well as in map-view: interpolated surfaces of both the ' 410 ' and the ' 660 ' were obtained by manual picking on both N-S and E-W oriented slices (Figures $2 \mathrm{~g}$ and $2 \mathrm{~h}$ ). Figures $2 \mathrm{~g}$ and $2 \mathrm{~h}$ demonstrate, at least in the well resolved parts (see auxiliary material) of our image, that the MTZ thickening is a result of the clear deepening of the ' 660 ', while the ' 410 ' shows no significant deviation.

[12] Our results broadly agree with previous investigations of the mantle transition zone beneath Central Europe based on reflected and refracted phases from regional events [Świeczak et al., 2004] and on RFs from fewer stations [Hetényi and Bus, 2007; Geissler et al., 2008], and bring a new, higher resolution, three-dimensional image of the MTZ in this region. The new images show variations in depth of the ' 660 ' conversions occurring with wavelengths on the order of $200 \mathrm{~km}$, forming visible undulations such as a bowl-shaped depression below the Eastern part of the Pannonian Basin (see the centre of profile $b$ and $c$, as well as the Eastern part of profile $d$ ), which are independent from variations in $\mathrm{V}_{\mathrm{P}} / \mathrm{V}_{\mathrm{S}}$ within the $\mathrm{MTZ}$ (see auxiliary material). Comparison of our results with those from a similar study of the Alps [Lombardi et al., 2009] raises important questions: in both cases the ' 660 ' is deeper by as much as $40 \mathrm{~km}$, yet Alpine geology has been dominated by continental convergence since $15 \mathrm{Ma}$, whereas the Pannonian system underwent 


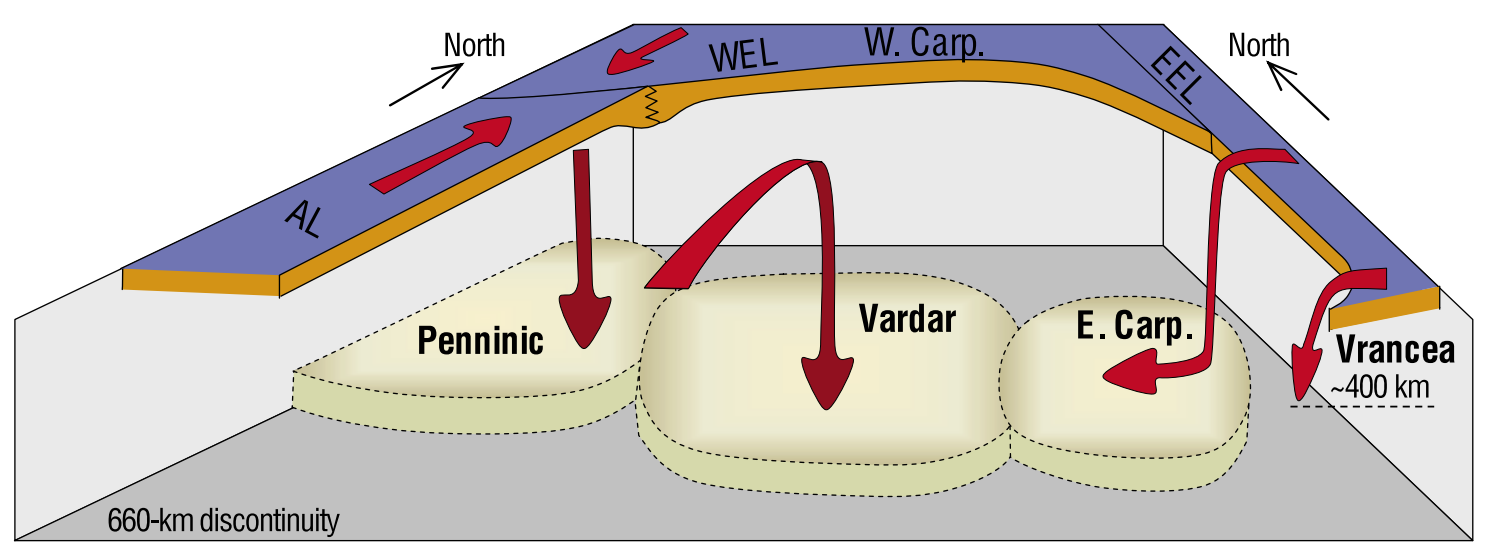

Figure 3. Schematic representation of lithospheric relationships and evolution in the Pannonian Basin region. Blue-yellow colors mark the Adriatic (AL), the West European (WEL) and the East European (EEL) lithospheres. Red arrows represent lithosphere movement paths along which lithospheric material have reached the mantle transition zone. The pale brown bodies represent the areas where the following ocean remnants have sunk: Penninic in the Cretaceous, Vardar in the Palaeogene, and the East Carpathian subduction in the Miocene. The next source of lithospheric material will be the arrival of the Vrancea zone into the mantle transition zone, currently extending down to a depth of $\sim 400 \mathrm{~km}$.

a phase of rapid extension followed by structural stabilization since 10 Ma. Is depression of the ' 660 ' in both regions actually related to lithospheric events that occurred prior to $10 \mathrm{Ma}$ or even earlier?

\section{Discussion and Conclusions}

[13] In the context of subduction, a thickened MTZ is usually interpreted in terms of a colder thermal regime than the ambient mantle temperatures [e.g., Lebedev et al., 2002]. In order to explain a $\sim 40 \mathrm{~km}$ MTZ thickening solely as an effect of temperature, a negative anomaly of the order of $300 \mathrm{~K}$ is required throughout the MTZ (considering Clapeyron-slopes of 2.9 and $-1.9 \mathrm{MPa} / \mathrm{K}$ for the ' 410 ' and the '660', respectively [Bina and Helffrich, 1994]). However, our results beneath the Pannonian-Carpathian region provide complementary information with better spatial resolution than earlier tomographic images [Wortel and Spakman, 2000; Piromallo and Morelli, 2003]. Thickening is mainly caused by deepening of the ' 660 ' without major variation in the depth of the ' 410 '. Direct conversion of these anomalies in depth to thermal anomalies at the interfaces using the above Clapeyron-slopes would imply normal mantle temperatures at the ' 410 ', and temperatures lower than normal by up to $800 \mathrm{~K}$ at the ' 660 '.

[14] In the light of tomography and RF results, and the geodynamic history of the region, we interpret the anomalously deep $660 \mathrm{~km}$ transition as a result of accumulation of cold, denser material. Similar magnitude deflections of the ' 660 ' are observed where subducting slabs are actively impinging on the lower mantle [Shearer and Masters, 1992; Li et al., 2000]. Such observations beneath the NW Pacific have been interpreted as showing the downward movement of the cold upper mantle through the petrological barrier of the $660 \mathrm{~km}$ discontinuity [Li and Yuan, 2003]. Observations similar to ours of a flat ' 410 ' but structurally complicated and deepened ' 660 ' have been described beneath the eastern part of the North China Craton [Chen and $A i, 2009]$ and interpreted as a stagnant slab with possible sporadic penetration into the lower mantle. One might also argue that localized depressions of the ' 660 ' are caused by ponding of relatively cold lithospheric mantle material, accumulated during different subduction or continental delamination events, but not yet penetrating the phase transition boundary. Non-olivine phase transitions, such as garnet $\rightarrow$ perovskite are also proposed to explain complex RF signature of the ' 660 ' as these can generate multiple discontinuities and velocity gradients [Andrews and Deuss, 2008]. Close examination of our images has not found clear evidence of such broadened or duplicated signal. The simplest explanation of this absence is that this recently deposited cold material of lithospheric provenance has not undergone the phase change associated with the ' 660 '.

[15] A schematic geodynamic interpretation of the provenance of subducted or delaminated lithospheric material is shown on Figure 3. Cold material in the MTZ has been accumulating since at least the Cretaceous, from sustained continental convergence and successive subduction of Neo-Tethys-related sub-basins. Associated with the collision of Africa with Europe, the Penninic oceanic fragment has sunk into the MTZ in the Cretaceous-Early Palaeogene [Csontos and Vörös, 2004; Schmid et al., 2008]. The Vardar Ocean, whose suture lies to the southwest of the Pannonian Basin has disappeared in a second stage of convergence during the Palaeogene [Csontos et al., 1992; Kovács et al., 2007], as has the Ligurian oceanic fragment west of the Apennines [Faccenna et al., 2004]. In the Miocene from 17 to $11 \mathrm{Ma}$ the Carpathian flysch basin lithosphere has been apparently consumed by the East Carpathian subduction zone [Horváth, 1993]. Though subduction ceased at $11 \mathrm{Ma}$, sinking of cold, possibly continental mantle towards the MTZ continues beneath the SE Carpathians at least [Lorinczi and Houseman, 2009]. At present, lithospheric material of different age and provenance occupies the MTZ (Figure 3): it is unlikely that these fragments continue to behave as slabs, but rather deform viscously as they are sheared and mixed by a continuing convective circulation. This complex history may explain the irregular lateral variation in depth of the ' 660 '. 
[16] The fact that cold material fills the MTZ beneath the Pannonian Basin, seen now by both tomography and receiver function images from independent data, has implications for the thermal regime and volcanism of the region. The observed high heat flow at surface [Horváth et al., 2005b], the slow seismic anomalies above the MTZ [Wortel and Spakman, 2000; Piromallo and Morelli, 2003], the high electrical conductivities [e.g., Ádám et al., 1989], and the potential upward displacement of hot material by the sinking slabs all call for a hot upper mantle. In addition dehydration of descending slabs [Ono, 2007] may have released water into the upper mantle, which triggered postMiocene volcanism in the Pannonian Basin [Harangi et al., 2007]. Although a plume originating in the lower mantle is proposed for continental European volcanic areas [Goes et $a l ., 1999]$, the downward deflection of the $660 \mathrm{~km}$ discontinuity almost everywhere beneath the Pannonian-Carpathian region implies that this plume is unlikely to have strongly impacted the upper mantle in this region. Indeed, an upper mantle source for the observed volcanism seems more probable, which is also supported by geochemistry, tomography and plate kinematics [Piromallo et al., 2008].

[17] In conclusion, the Pannonian Basin is a region with a complex geodynamical history of subduction, lithospheric deformation and gravitational instability reflected now in structures observed in the mantle transition zone. The history of subduction events and continuing lithospheric instability integrated over Cretaceous and Cenozoic times explains in principle the observed thickening of the MTZ which is now imaged here in unprecedented detail.

[18] Acknowledgments. The authors are grateful for the help of others in the CBP Working Group (S. Radovanovic, A. Brisbourne, A. Horleston, D. Hawthorn, P. Lorinczi, B. Dando, G. Falus, A. Kovács, I. Török, H. Hausmann, W. Loderer, V. Kovacevic, S. Petrovic-Cacic, D. Valcic), as well as to the following institutes: SEIS-UK for providing the seismological stations for the Carpathian Basins Project; GEOFON, ORFEUS and IRIS repositories for permanent station data; as well as the Geodetic and Geophysical Research Institute of the Hungarian Academy of Sciences for granting access to permanent station data in Hungary. Many thanks to Claudia Piromallo who provided immediate access to the PM05 velocitymodel. The paper benefited from constructive and concise reviews from two anonyms, as well as from discussions with George Helffrich, Sebastian Rost and Marjorie Wilson. Figures 1, 2 and S1 were produced using the Generic Mapping Tool [Wessel and Smith, 1991]. The Carpathian Basins Project was funded by NERC standard grant NE/C004574/1.

\section{References}

Ádám, A., K. Landy, and Z. Nagy (1989), New evidence for the distribution of the electric conductivity in the Earth's crust and upper mantle in the Pannonian Basin as a "hotspot," Tectonophysics, 164, 361-368, doi:10.1016/0040-1951(89)90027-9.

Andrews, J., and A. Deuss (2008), Detailed nature of the $660 \mathrm{~km}$ region of the mantle from global receiver function data, J. Geophys. Res., 113, B06304, doi:10.1029/2007JB005111.

Bada, G., F. Horváth, P. Gerner, and I. Fejes (1999), Review of the presentday geodynamics of the Pannonian basin: Progress and problems, J. Geodyn., 27, 501-527, doi:10.1016/S0264-3707(98)00013-1.

Bina, C. R., and G. Helffrich (1994), Phase transition Clapeyron slopes and transition zone seismic discontinuity topography, J. Geophys. Res., 99, 15,853-15,860, doi:10.1029/94JB00462.

Brückl, E., et al. (2007), Crustal structure due to collisional and escape tectonics in the Eastern Alps region based on profiles Alp01 and Alp02 from the ALP 2002 seismic experiment, J. Geophys. Res., 112, B06308, doi:10.1029/2006JB004687.

Chen, L., and Y. Ai (2009), Discontinuity structure of the mantle transition zone beneath North China Craton from receiver function migration, J. Geophys. Res., 114, B06307, doi:10.1029/2008JB006221.

Chevrot, S., L. Vinnik, and J.-P. Montagner (1999), Global-scale analysis of the mantle $P d s$ phases, J. Geophys. Res., 104, 20,203-20,219, doi:10.1029/1999JB900087.
Csontos, L., and A. Vörös (2004), Mesozoic plate tectonic reconstruction of the Carpathian region, Palaeogeogr. Palaeoclimatol. Palaeoecol., 210, 1-56, doi:10.1016/j.palaeo.2004.02.033.

Csontos, L., A. Nagymarosy, F. Horváth, and M. Kovác (1992), Tertiary evolution of the Intra-Carpathian area: A model, Tectonophysics, 208 , 221-241, doi:10.1016/0040-1951(92)90346-8.

Faccenna, C., C. Piromallo, A. Crespo-Blanc, L. Jolivet, and F. Rossetti (2004), Lateral slab deformation and the origin of the western Mediterranean arcs, Tectonics, 23, TC1012, doi:10.1029/2002TC001488.

Geissler, W. H., R. Kind, and X. H. Yuan (2008), Upper mantle and lithospheric heterogeneities in central and eastern Europe as observed by teleseismic receiver functions, Geophys. J. Int., 174, 351-376, doi:10.1111/j.1365-246X.2008.03767.x.

Goes, S., W. Spakman, and H. Bijwaard (1999), A lower mantle source for central European volcanism, Science, 286, 1928-1931, doi:10.1126/ science.286.5446.1928.

Harangi, S., H. Downes, M. Thirlwall, and K. Gméling (2007), Geochemistry, petrogenesis and geodynamic relationships of Miocene calc-alkaline volcanic rocks in the Western Carpathian Arc, eastern central Europe, J. Petrol., 48, 2261-2287, doi:10.1093/petrology/egm059.

Hetényi, G., and Z. Bus (2007), Shear wave velocity and crustal thickness in the Pannonian Basin from receiver function inversions at four permanent stations in Hungary, J. Seismol., 11, 405-414, doi:10.1007/s10950-0079060-4.

Horváth, F. (1993), Towards a mechanical model for the formation of the Pannonian Basin, Tectonophysics, 226, 333-357, doi:10.1016/00401951(93)90126-5.

Horváth, F., and L. Royden (1981), Mechanism for the formation of the Intra-Carpathian Basins: A review, Earth Evol. Sci., 3-4, 307-316.

Horváth, F., G. Bada, P. Szafián, G. Tari, A. Ádám, and S. Cloething (2005a), Formation and deformation of the Pannonian basin: Constraints from observational data, in European Lithosphere Dynamics, edited by D. Gee and R. Stephenson, Geol. Soc. London Mem., 32, 191-206.

Horváth, F., et al. (2005b), Atlas of the present-day geodynamics of the Pannonian Basin: Euroconform maps with explanatory text, Eötvös Loránd Univ., Budapest. (Available at http://geophysics.elte.hu/projektek/ geodinamikai_atlasz_eng.htm)

Houseman, G. A.., and L. Gemmer (2007), Intra-orogenic extension driven by gravitational instability: Carpathian-Pannonian orogeny, Geology, 35, 1135-1138, doi:10.1130/G23993A.1

Kovács, I., L. Csontos, C. Szabó, E. Bali, G. Falus, K. Benedek, and Z. Zajacz (2007), Paleogene-early Miocene igneous rocks and geodynamics of the Alpine-Carpathian-Pannonian-Dinaric region: An integrated approach, in Cenozoic Volcanism in the Mediterranean Area, edited by L. Beccaluva et al., Geol. Soc. Am. Spec. Pap., 418, 93-112.

Langston, C. (1979), Structure under Mount Rainier, Washington, inferred from teleseismic body waves, J. Geophys. Res., 84, 4749-4762, doi:10.1029/JB084iB09p04749.

Lawrence, J. F., and P. M. Shearer (2006), A global study of transition zone thickness using receiver functions, J. Geophys. Res., 111, B06307, doi:10.1029/2005JB003973.

Lebedev, S., S. Chevrot, and R. D. van der Hilst (2002), Seismic evidence for olivine phase changes at the 410-and 660-kilometer discontinuities, Science, 296, 1300-1302, doi:10.1126/science.1069407.

Li, X. Q., and X. H. Yuan (2003), Receiver functions in northeast ChinaImplications for slab penetration into the lower mantle in northwest Pacific subduction zone, Earth Planet. Sci. Lett., 216, 679-691, doi:10.1016/S0012-821X(03)00555-7.

Li, X., S. V. Sobolev, R. Kind, X. Yuan, and C. Estabrook (2000), A detailed receiver function image of the upper mantle discontinuities in the Japan subduction zone, Earth Planet. Sci. Lett., 183, 527-541, doi:10.1016/S0012-821X(00)00294-6.

Lombardi, D., J. Braunmiller, E. Kissling, and D. Giardini (2009), Alpine mantle transition zone imaged by receiver functions, Earth Planet. Sci. Lett., 278, 163-174, doi:10.1016/j.eps1.2008.11.029.

Lorinczi, P., and G. A. Houseman (2009), Lithospheric gravitational instability beneath the Southeast Carpathians, Tectonophysics, doi:10.1016/ j.tecto.2008.05.024, in press.

Ono, S. (2007), The Lehmann discontinuity due to dehydration of subducted sediment, Open Mineral. J., 1, 1-4.

Piromallo, C., and A. Morelli (2003), $P$ wave tomography of the mantle under the Alpine-Mediterranean area, J. Geophys. Res., 108(B2), 2065, doi:10.1029/2002JB001757.

Piromallo, C., D. Gasperini, P. Macera, and C. Faccenna (2008), A late Cretaceous contamination episode of the European-Mediterranean mantle, Earth Planet. Sci. Lett., 268, 15-27, doi:10.1016/j.epsl.2007.12.019.

Schmid, S. M., D. Bernouilli, B. Fügenschuh, L. Matenco, S. Schefer, R. Schuster, M. Tischler, and K. Ustaszewski (2008), The AlpineCarpathian-Dinaridic orogenic system: Correlation and evolution of tectonic units, Swiss J. Geosci., 101, 139-183, doi:10.1007/s00015$008-1247-3$. 
Shearer, P. M., and G. Masters (1992), Global mapping of topography on the 660-km discontinuity, Nature, 355, 791-796, doi:10.1038/355791a0.

Środa, P., W. Czuba, M. Grad, A. Guterch, A. K. Tokarski, T. Janik M. Rauch, G. R. Keller, E. Hegedüs, J. Vozár, and the CELEBRATION 2000 Working Group (2006), Crustal and upper mantle structure of the Western Carpathians from CELEBRATION 2000 profiles CEL01 and CEL04: Seismic models and geological implications, Geophys. J. Int. 167, 737-760, doi:10.1111/j.1365-246X.2006.03104.x.

Stampfli, G. M., and G. D. Borel (2004), The TRANSMED transects in space and time: Constraints on the paleotectonic evolution of the Mediterranean domain, in The TRANSMED Atlas: The Mediterranean Region from Crust to Mantle, edited by W. Cavazza et al., pp. 53-80, Springer, Heidelberg, Germany.

Świeczak, M., M. Grad, and the TOR and SVEKALAPKO Working Groups (2004), Upper mantle seismic discontinuities topography variations beneath eastern Europe, Acta Geophys. Pol., 52, 251-270.

Wessel, P., and W. H. F. Smith (1991), Free software helps map and display data, Eos Trans. AGU, 72(41), 441, doi:10.1029/90EO00319.
Wortel, M. J. T., and W. Spakman (2000), Subduction and slab detachment in the Mediterranean-Carpathian region, Science, 290, 1910-1917, doi:10.1126/science.290.5498.1910.

Zhu, L. P. (2000), Crustal structure across the San Andreas Fault, southern California from teleseismic converted waves, Earth Planet. Sci. Lett., 179, 183-190, doi:10.1016/S0012-821X(00)00101-1.

E. Brückl, Institute of Geodesy and Geophysics, Technische Universität Wien, Gusshausstrasse 27-29, A-1040 Vienna, Austria.

E. Hegedüs, Eötvös Loránd Geophysical Institute, Kolumbusz utca 17-23, H-1145 Budapest, Hungary.

G. Hetényi, Department of Earth Sciences, ETH Zurich, CH-8092 Zürich, Switzerland. (gyorgy.hetenyi@erdw.ethz.ch)

F. Horváth, Department of Geophysics, Eötvös University, Pázmány Péter sétány 1/C, H-1117 Budapest, Hungary.

G. A. Houseman and G. W. Stuart, School of Earth and Environment, University of Leeds, Leeds LS2 9JT, UK. 